\title{
LACTOFERRIN VERSUS FERROUS SULPHATE FOR THE TREATMENT OF IRON DEFICIENCY ANEMIA DURING PREGNANCY (A RANDOMIZED CLINICAL TRIAL)
}

\author{
By
}

\section{Mofeed Fawzy Mohamed, Wael Soliman Taha and Mohamed Farrag Ismaeil Farag*}

Obstetrics and Gynecology Department, Faculty of Medicine, Al-Azhar University, Cairo, Egypt

*Corresponding Author: Mohamed Farrag Ismaeil Farag

Phone No.: (+2) 01064717497

E-mail: mohammad.farrag.mf@gmail.com

\begin{abstract}
Background: Iron deficiency anemia (IDA) is the condition in which there is decrease in the number of red blood cells or the amount of hemoglobin in the blood. It is caused by insufficient dietary intake and absorption of iron, or iron loss from bleeding. Bleeding can be from a range of sources such as the intestinal, uterine or urinary tract. IDA develops when available iron is insufficient to support normal red cell production and is the most common type of anemia.
\end{abstract}

Objective: Comparing the efficacy and the safety of Lactoferrin versus ferrous sulphate for the treatment of iron deficiency anemia during pregnancy.

Patients and Methods: This study was done in outpatient clinic of El-Monera General Hospital, from January 2019 to March 2019, between two groups of pregnant women ranging from 20-40 years and gestational age 24-32 weeks with microcytic hypochromic anemia, mild anemia and moderate anemia for 2 months that were selected in a randomized method by the computer.

Results: Oral lactoferrin was better tolerated and more acceptable with higher increase in mean hemoglobin when compared to oral iron therapy over two months treatment.

Conclusion: Oral lactoferrin was better tolerated and more acceptable with higher increase in mean hemoglobin when compared to oral iron therapy over two months treatment.

Keywords: Lactoferrin - Ferrous Sulphate - Iron Deficiency Anemia.

\section{INTRODUCTION}

Anemia has a significant impact on the health of the fetus as well as that of the mother. It impairs the oxygen delivery through the placenta to the fetus and interferes with the normal intrauterine growth, leading to fetal loss and perinatal deaths. Anemia is associated with increased preterm labor (28.2\%), preeclampsia (31.2\%), and maternal sepsis (Hutter and Jaeggi, 2010).

Iron homeostasis is tightly regulated through iron absorption, storage and transport (Duck and Connor, 2016). 
Significant decreases of total serum iron and serum ferritin combined with increases of serum IL-6 have been observed in pregnant women (Paesano et al., 2010) and in haemodialysis patients treated with oral ferrous sulfate, these results strongly support the possibility that iron supplemented via ferrous sulfate is not exported from cells to circulation, but it is accumulated inside host cells resulting in inflammatory conditions (Baker and Baker, 2012).This evidence has raised serious questions regarding the safety/efficacy of oral ferrous sulfate, resulting in new approaches for treating ID and IDA and avoiding toxicities associated with iron overload (Paesano et al., 2010).

The oral route is the first choice to replace iron stores as this allows the normal mechanism of absorption to be used, in addition to being an inexpensive and effective treatment (Hutter and Jaeggi, 2010).

Lactoferrin (formerly known as lacto transferrin) is a glycoprotein, and a member of a transferrin family, thus belonging to those proteins capable of binding and transferring iron (Nocerino et al., 2014).

Lactoferrin is a protein found in cow milk and human milk. Colostrum, the first milk produced after a baby is born, contains high levels of lactoferrin, about seven times the amount found in milk produced later on (Kochhar et al., 2013). Its actions are mediated by specific receptors, by direct effect on the cellular membrane wall, competition for the iron ions or through its enzymatic function, only to mention few mechanisms through which it realizes all these activities. Its properties are facilitated by its capacity of maintaining the iron bound in low $\mathrm{pH}$ environment, as well as the ability to bind to other substances, such as lipopolysaccharides, heparin, glycosaminoglycans, DNA, oxalates, carboxylates, or other metallic ions $(\mathrm{Al} 3+$, $\mathrm{Ga} 3+, \mathrm{Mn} 3+, \quad \mathrm{Co} 3+, \quad \mathrm{Cu} 2+, \quad \mathrm{Zn} 2+)$ (Sharma and Meenakshi, 2014).

A previous study was published in April 2010, about (Lactoferrin efficacy versus ferrous sulfate in curing iron deficiency and iron deficiency anemia in pregnant women) and found that lactoferrin represent an extremely valid natural drug which, without any adverse effects, prevents and cures IDA more effectively than ferrous sulfate (Paesano et al., 2010).

The present study aimed to compare the efficacy and the safety of Lactoferrin versus ferrous sulphate for the treatment of iron deficiency anemia during pregnancy.

\section{PATIENTS AND METHODS}

The study included two groups of pregnant women that were randomized by the computer in two groups:

Group 1 (Lactoferrin plus folic acid group) included 100 pregnant women who received lactoferrin 100 (Pravotin100 mg sachets, Hygint, Egypt) + once daily orally for 2 months.

Group 2 (Ferrous Sulphate group) included 100 pregnant women who received $150 \mathrm{mg}$ of dried ferrous sulphate capsules (Ferrofol capsules, EIPICO, Egypt) once daily orally for 2 months.

Patients were assigned to take the medication orally; once daily before 


\section{LACTOFERRIN VERSUS FERROUS SULPHATE FOR THE TREATMENT...}

breakfast, and Pravotin (100 sachets were be dissolved each in $1 / 4$ glass of water and taken before breakfast). Patients were advised to avoid the intake of tea, coffee, milk, milk products, antacids and calcium preparation within 2 hours before or after iron capsules.

Women of both groups were selected from pregnant women attending the antenatal outpatient clinic of Al-Monera General Hospital started from January 2019 to march 2019 according to the following eligibility criteria:

\section{Inclusion criteria:}

- Age: 20-40 years.

- Pregnant women with iron deficiency anemia.

- Microcytic hypochromic anemia, mild anemia ( $\mathrm{Hb} 10$ to $10.9 \mathrm{~g} / \mathrm{dl})$ and moderate anemia ( $\mathrm{Hb} 7$ to $9.9 \mathrm{~g} / \mathrm{dl}$ ) as per WHO guidelines and S.Ferritin levels $<25 \mathrm{ng} / \mathrm{dl}$.

- Gestational age: 24-32 weeks.

- Singleton viable pregnancy.

\section{Exclusion criteria:}

- Women with a history of anemia due to any other cause such as chronic blood loss, hemolytic anemia, and thalassemia (including thalassemia trait).

- Severe anemia $(<7 \mathrm{~g} / \mathrm{dl})$ requiring blood transfusion, bronchial asthma, clinical and/or laboratory evidence of hepatic, renal, hematologic or cardiovascular abnormalities.

- History of peptic ulcer, hypersensitivity to iron preparations and treatment with any other iron preparation in the last one month before study entry and suspected acute infection.

All women in the study were submitted to complete history taking, general examination, abdominal examination and U/S investigation. They were also subjected to complete blood count and serum ferritin.

Determine the hemoglobin difference and serum ferritin level were repeated after 1 month and 2 months after treatment.

\section{Primary outcome:}

The primary outcome was to determine the hemoglobin difference and serum ferritin level 2 months after treatment.

\section{Secondary outcome:}

- Nausea, vomiting and GIT upset.

- Compliance of the treatment.

- Constipation.

- Cost effectiveness.

\section{Ethical Aspects:}

The study protocol was in agreement to the Helsinki's Principles of Ethical Medical Research [last updated in Brazil 2013]. All women signed informed written consents before participating in the study after thorough explanation of the purpose and procedure of the study.

Sample size was calculated using Power and Sample Size Calculator, setting the power at $80 \%$ and the type- 1 error at 0.05. Data from a previous very similar trial showed that the mean increase in $\mathrm{Hb}$ concentration after treatment was $2.28 \pm$ $0.56 \mathrm{~g} / \mathrm{dl}$ and $1.16 \pm 0.42 \mathrm{~g} / \mathrm{dl}$ in women who received lactoferrin and those who 


\section{MOFEED FAWZY MOHAMED et al.,}

received ferrous sulfate, respectively (Rezk et al., 2015).

Statistical analysis was performed using Microsoft Excel version 2015 and SPSS for Windows version 20.0. Data are to be presented in terms of range, mean and standard deviation (for numeric parametric variables); range, median and interquartile range (for numeric nonparametric); or number and percentage (for categorical variables). Difference between the two groups is to be analyzed using Mann-Whitney's U-test, and mean difference with its 95\% CI (for numeric parametric variables); Mann-Whitney's U-test (for numeric non-parametric); or chi-squared test and risk ratio with its 95\% CI (for categorical variables). Significance level was set at $<0.05$.

\section{RESULTS}

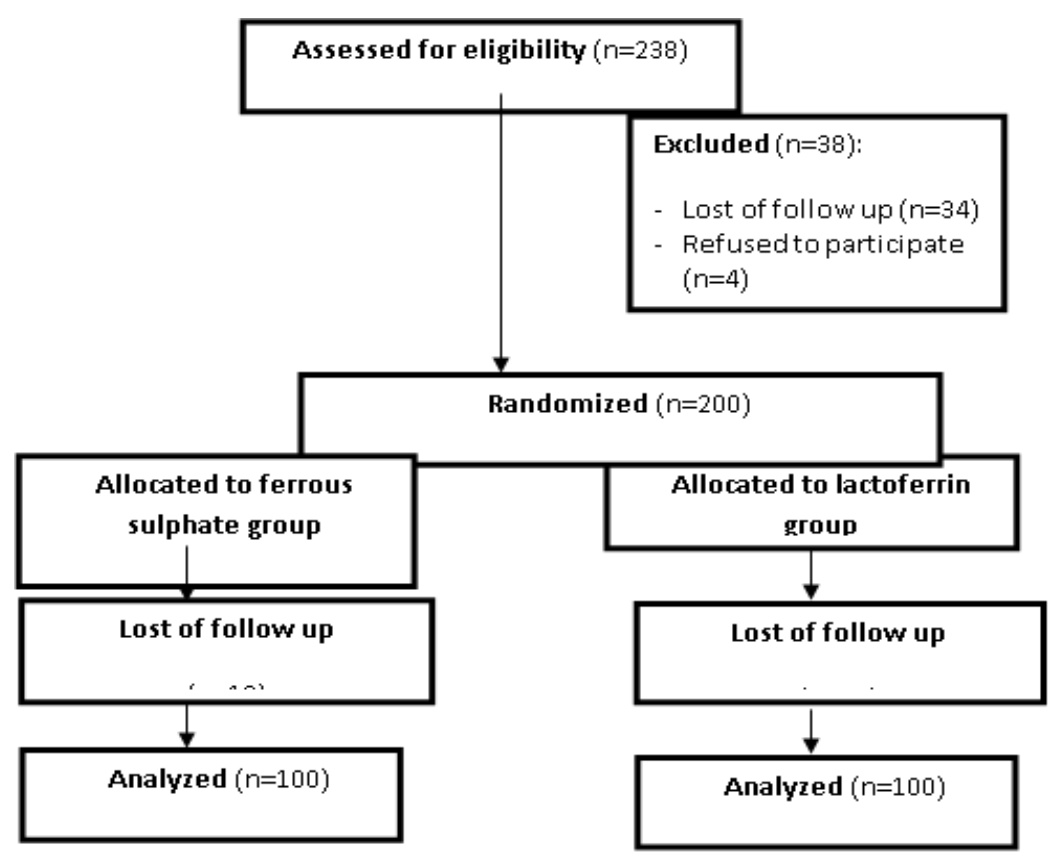

Figure (1): Consort, Patient flow chart

No significant difference between ferrous sulphate and lactoferrin groups regarding demographic characteristics. 
LACTOFERRIN VERSUS FERROUS SULPHATE FOR THE TREATMENT...

Table (1): Demographic characteristics among the studied groups

\begin{tabular}{|c|c|c|c|c|}
\hline Variables & Measures & $\begin{array}{c}\text { Lactoferrin } \\
(\mathrm{N}=100)\end{array}$ & $\begin{array}{l}\text { Ferrous sulphate } \\
(\mathbf{N}=100)\end{array}$ & $\mathbf{P}$ \\
\hline \multirow{2}{*}{$\begin{array}{c}\text { Age } \\
\text { (years) }\end{array}$} & Mean \pm SD & $30.7 \pm 4.4$ & $29.5 \pm 4.7$ & \multirow{2}{*}{$>0.05$} \\
\hline & Range & $20.0-39.0$ & $21.0-39.0$ & \\
\hline \multirow{2}{*}{$\begin{array}{c}\text { BMI } \\
\left(\mathrm{kg} / \mathrm{m}^{2}\right)\end{array}$} & Mean \pm SD & $28.7 \pm 1.6$ & $28.3 \pm 1.8$ & \multirow{2}{*}{$>0.05$} \\
\hline & Range & $26.0-31.6$ & $25.3-31.4$ & \\
\hline \multirow{2}{*}{$\begin{array}{l}\text { Parity } \\
(n, \%)\end{array}$} & Primigravida & $24(24.0 \%)$ & $28(28.0 \%)$ & \multirow{2}{*}{$>0.05$} \\
\hline & Multigravida & $76(76.0 \%)$ & $72(72.0 \%)$ & \\
\hline \multirow{2}{*}{$\begin{array}{c}\text { GA } \\
\text { (weeks) }\end{array}$} & Mean \pm SD & $18.9 \pm 2.8$ & $19.3 \pm 2.9$ & \multirow{2}{*}{$>0.05$} \\
\hline & Range & $13.0-26.0$ & $13.0-26.0$ & \\
\hline \multirow{2}{*}{$\begin{array}{c}\text { Anemia grade } \\
(n, \%)\end{array}$} & Mild & $18(18.0 \%)$ & $16(16.0 \%)$ & \multirow{2}{*}{$>0.05$} \\
\hline & Moderate & $82(82.0 \%)$ & $84(84.0 \%)$ & \\
\hline
\end{tabular}

No significant difference between ferrous sulphate and lactoferrin groups regarding basal hemoglobin. Hemoglobin significantly increased in ferrous sulphate and lactoferrin groups at month-1 and at month-2 after treatment. Hemoglobin at month-1 and at month-2 after treatment was significantly higher in lactoferrin group than in ferrous sulphate group. Hemoglobin elevation at month-1 and at month-2 after treatment was significantly higher in lactoferrin group than in ferrous sulphate group.

Table (2): Hemoglobin (g/dl) among the studied groups

\begin{tabular}{|c|c|c|c|c|}
\hline Time & Measures & $\begin{array}{c}\text { Lactoferrin } \\
(\mathrm{N}=\mathbf{1 0 0})\end{array}$ & $\begin{array}{c}\text { Ferrous sulphate } \\
(\mathbf{N}=100)\end{array}$ & ${ }^{\wedge} \mathbf{P}$ \\
\hline \multirow{2}{*}{ Basal } & Mean \pm SD & $8.9 \pm 0.9$ & $9.2 \pm 0.9$ & \multirow{2}{*}{$>0.050$} \\
\hline & Range & $7.3-10.5$ & $7.2-10.7$ & \\
\hline \multirow{2}{*}{ Month-1 } & Mean \pm SD & $10.1 \pm 0.9$ & $9.7 \pm 0.9$ & \multirow{2}{*}{$<0.002$} \\
\hline & Range & $8.4-12.1$ & $7.5-11.5$ & \\
\hline \multirow{2}{*}{ Month-2 } & \multirow{2}{*}{$\frac{\text { Mean } \pm \text { SD }}{\text { Range }}$} & $11.4 \pm 1.1$ & $10.2 \pm 1.2$ & \multirow{2}{*}{$<0.001$} \\
\hline & & $9.3-13.8$ & $7.6-13.1$ & \\
\hline \multirow{3}{*}{$\begin{array}{c}\text { Change } \\
\text { At } \\
\text { Month-1 }\end{array}$} & Mean \pm SD & $1.1 \pm 0.2$ & $0.5 \pm 0.2$ & \multirow{2}{*}{$<0.001$} \\
\hline & Range & $0.7-1.6$ & $0.1-0.9$ & \\
\hline & $\# \mathbf{P}$ & $<0.001 *$ & $<0.001 *$ & \\
\hline \multirow{3}{*}{$\begin{array}{c}\text { Change } \\
\text { At } \\
\text { Month-2 }\end{array}$} & \multirow{2}{*}{$\begin{array}{c}\text { Mean } \pm \text { SD } \\
\text { Range }\end{array}$} & $2.5 \pm 0.4$ & $1.1 \pm 0.6$ & \multirow{2}{*}{$<0.001$} \\
\hline & & $1.6-3.5$ & $0.0-2.6$ & \\
\hline & $\# \mathbf{P}$ & $<0.001 *$ & $<0.001 *$ & \\
\hline \multicolumn{5}{|c|}{ Impact of lactoferrin over ferrous sulphate on $\mathrm{Hb}$ elevation } \\
\hline \multicolumn{2}{|c|}{ Time } & \multicolumn{2}{|c|}{\begin{tabular}{|l|r} 
Mean \pm SE & $95 \%$
\end{tabular}} & \\
\hline \multirow{2}{*}{\multicolumn{2}{|c|}{ Month-1 }} & $0.6 \pm 0.1$ & \multicolumn{2}{|c|}{$0.5-0.7$} \\
\hline & & $1.4 \pm 0.1$ & \multicolumn{2}{|c|}{$1.2-1.7$} \\
\hline
\end{tabular}

${ }^{\wedge}$ Mann-Whitney test, \#Wilcoxon Rank test, CI: Confidence interval

No significant difference between ferrous sulphate and lactoferrin groups regarding basal serum ferritin. Serum ferritin significantly increased in ferrous sulphate and lactoferrin groups at month-1 and at month-2 after treatment. Serum ferritin at month-1 and at month-2 after treatment was significantly higher in lactoferrin group than in ferrous sulphate group. Serum ferritin elevation at month-1 and at month-2 after treatment was significantly higher in lactoferrin group than in ferrous sulphate group. 
Table (3): Serum ferritin (ng/dl) among the studied groups

\begin{tabular}{|c|c|c|c|c|}
\hline Time & Measures & $\begin{array}{c}\text { Lactoferrin } \\
(\mathrm{N}=\mathbf{1 0 0})\end{array}$ & $\begin{array}{l}\text { Ferrous sulphate } \\
(\mathbf{N}=\mathbf{1 0 0})\end{array}$ & ${ }^{\wedge} \mathbf{P}$ \\
\hline \multirow{2}{*}{ Basal } & Mean \pm SD & $9.4 \pm 1.7$ & $10.0 \pm 1.9$ & \multirow{2}{*}{$<0.001$} \\
\hline & Range & $6.0-13.0$ & $5.7-15.0$ & \\
\hline \multirow{2}{*}{ Month-1 } & Mean \pm SD & $14.1 \pm 2.2$ & $13.2 \pm 2.3$ & \multirow{2}{*}{$<0.001$} \\
\hline & Range & $9.9-19.3$ & $7.4-18.1$ & \\
\hline \multirow{2}{*}{ Month-2 } & Mean \pm SD & $18.4 \pm 2.6$ & $15.5 \pm 3.0$ & \multirow{2}{*}{$<0.001$} \\
\hline & Range & $12.9-23.5$ & $9.1-23.1$ & \\
\hline \multirow{3}{*}{$\begin{array}{c}\text { Change } \\
\text { At } \\
\text { Month-1 } \\
\end{array}$} & \multirow{2}{*}{$\begin{array}{c}\text { Mean } \pm \text { SD } \\
\text { Range }\end{array}$} & $4.7 \pm 0.7$ & $3.2 \pm 0.7$ & \multirow{2}{*}{$<0.001$} \\
\hline & & $3.3-6.7$ & $0.7-4.4$ & \\
\hline & $\# \mathbf{P}$ & $<0.001$ & $<0.001$ & \\
\hline \multirow{3}{*}{$\begin{array}{c}\text { Change } \\
\text { At } \\
\text { Month-2 } \\
\end{array}$} & Mean \pm SD & $9.0 \pm 1.3$ & $5.5 \pm 1.7$ & \multirow{2}{*}{$<0.001$} \\
\hline & \multirow{2}{*}{$\begin{array}{c}\text { Range } \\
\# \mathbf{P} \\
\end{array}$} & $5.7-11.5$ & $2.1-9.4$ & \\
\hline & & $<0.001$ & $<0.001$ & \\
\hline \multicolumn{5}{|c|}{ Impact of lactoferrin over ferrous sulphate on ferritin elevation } \\
\hline \multicolumn{2}{|c|}{ Time } & \multicolumn{2}{|l|}{ Mean \pm SE } & $95 \% \mathrm{CI}$ \\
\hline \multirow{2}{*}{\multicolumn{2}{|c|}{ Month-1 }} & \multicolumn{2}{|l|}{$1.5 \pm 0.1$} & $1.2-1.8$ \\
\hline & Month-2 & $3.5 \pm 0.3$ & & $2.9-4.1$ \\
\hline
\end{tabular}

$\wedge^{\wedge}$ Mann-Whitney test, \#Wilcoxon Rank test, CI: Confidence interval

Maternal poor compliance and side effects were significantly more frequent in ferrous sulphate group than in lactoferrin group.

Table (4): Maternal compliance and side effects among the studied groups

\begin{tabular}{|c|c|c|c|c|}
\hline Findings & $\begin{array}{c}\text { Lactoferrin } \\
(\mathbf{N = 1 0 0})\end{array}$ & $\begin{array}{c}\text { Ferrous sulphate } \\
(\mathbf{N = 1 0 0})\end{array}$ & $\wedge$ P & $\begin{array}{c}\text { RR } \\
(\mathbf{9 5 \%} \mathbf{C I})\end{array}$ \\
\hline Abdominsl pain & $18(18.0 \%)$ & $68(68.0 \%)$ & $<\mathbf{0 . 0 0 1}$ & $0.291(0.159-0.532)$ \\
\hline Gastric upset & $14(14.0 \%)$ & $58(58.0 \%)$ & $<\mathbf{0 . 0 0 1}$ & $0.289(0.146-0.575)$ \\
\hline Nausea & $12(12.0 \%)$ & $46(46.0 \%)$ & $<\mathbf{0 . 0 0 1}$ & $0.334(0.160-0.697)$ \\
\hline Vomiting & $6(6.0 \%)$ & $38(38.0 \%)$ & $<\mathbf{0 . 0 0 1}$ & $0.226(0.078-0.658)$ \\
\hline Constipation & $14(14.0 \%)$ & $56(56.0 \%)$ & $<\mathbf{0 . 0 0 1}$ & $0.302(0.152-0.600)$ \\
\hline Black stool & $2(2.0 \%)$ & $46(46.0 \%)$ & $<\mathbf{0 . 0 0 1}$ & $0.065(0.009-0.443)$ \\
\hline $\begin{array}{c}\text { Poor } \\
\text { compliance }\end{array}$ & $4(4.0 \%)$ & $24(24.0 \%)$ & $\mathbf{0 . 0 0 1}$ & $0.256(0.070-0.936)$ \\
\hline
\end{tabular}

${ }^{\wedge}$ Chi square test, RR: Relative risk, CI: Confidence interval

Cost effectiveness at month-2 after treatment was significantly lower (more expensive) in lactoferrin group than in ferrous sulphate group. This based on the cost of total course of lactoferrin 280 Egyptian pounds, while that of ferrous sulphate is 12 Egyptian pounds.

Table (5): Cost effectiveness (Egyptian pound/Hemoglobin gm elevation) among the studied groups

\begin{tabular}{|c|c|c|c|}
\hline Measures & Lactoferrin $(\mathbf{N}=\mathbf{1 0 0})$ & Ferrous sulphate $(\mathbf{N}=\mathbf{1 0 0})$ & \multirow{2}{*}{$\mathbf{<}$} \\
\hline Mean \pm SD & $232.0 \pm 43.4$ & $18.5 \pm 6.4$ & \\
\hline Range & $160.0-350.0$ & $12-24$ \\
\hline \multicolumn{4}{|c|}{ Impact of lactoferrin over ferrous sulphate on cost elevation } \\
\hline Time & \multicolumn{2}{|c|}{ Mean \pm SE } & 95\% CI \\
\hline Month-2 & $213.5 \pm 4.387$ & $204.849-222.151$ \\
\hline
\end{tabular}

${ }^{\wedge}$ Mann-Whitney test, , CI: Confidence interval 


\section{LACTOFERRIN VERSUS FERROUS SULPHATE FOR THE TREATMENT...}

\section{DISCUSSION}

Iron deficiency anemia (IDA) is the condition in which there is decrease in the number of red blood cells or the amount of hemoglobin in the blood. It is caused by insufficient dietary intake and absorption of iron, or iron loss from bleeding. Bleeding can be from a range of sources such as the intestinal, uterine or urinary tract. IDA develops when available iron is insufficient to support normal red cell production and is the most common type of anemia (Stedman's Medical Dictionary, 2006).

Anemia has a significant impact on the health of the fetus as well as that of the mother. It impairs the oxygen delivery through the placenta to the fetus and interferes with the normal intrauterine growth, leading to fetal loss and perinatal deaths. Anemia is associated with increased preterm labor, preeclampsia, and maternal sepsis (Hutter and Jaeggi, 2010).

Ferrous sulfate is the most widely used iron preparation throughout the world. However, despite efficacy and low cost, this drug is associated with high rate of side effects, mainly affecting the gastrointestinal system (Tolkien et al., 2015).

Lactoferrin was first identified in milk and then in other human epithelial secretions and barrier body fluids. Many different functions have been attributed to lactoferrin, including protection from iron induced lipid peroxidation, immunemodulation and cell growth regulation and transcriptional activation of specific DNA sequences (Kochhar et al., 2013).
Lactoferrin also seems to be involved with regulation of bone marrow function (myelopoiesis), and it seems to be able to boost the body's defense (immune) system. Lactoferrin is a multifunctional protein exhibiting both dependent and independent biological activity based upon its iron binding capacity (Paesano et al., 2010).

Its actions are mediated by specific receptors, by direct effect on the cellular membrane wall, competition for the iron ions or through its enzymatic function (Sharma and Meenakshi, 2014).

Its proprieties are facilitated by its capacity of maintaining the iron bound in low $\mathrm{pH}$ environment, as well as the ability to bind to other substances, such as lipopolysaccharides, heparin, glycosaminoglycans, DNA, oxalates, carboxylates, or other metallic ions $(\mathrm{Al} 3+$, $\mathrm{Ga} 3+, \mathrm{Mn} 3+, \mathrm{Co} 3+, \mathrm{Cu} 2+, \mathrm{Zn} 2+$ (Sharma and Meenakshi, 2014).

We aimed in this study to compare the efficacy and the safety of Lactoferrin versus ferrous sulphate for the treatment of iron deficiency anemia during pregnancy.

This study was done in outpatient clinic of Al-Monira General Hospital between two groups of pregnant women ranging from 20-40 years and gestational age 24-32 weeks with microcytic hypochromic anemia, mild anemia and moderate anemia for 2 months who were selected in a randomized method by the computer.

All patients were subjected to full history taking, full clinical examination, obstetric history, symptoms of anemia, 
past history and General Examination, doing CBC and serum ferritin.

Our study show that no significant difference between ferrous sulphate and lactoferrin groups regarding demographic characteristics.

In our study, the results show that total increase in hemoglobin after 2 months with lactoferrin was higher compared to ferrous sulfate.

Indeed, during the 60 days' period of administration we observed no significant difference between ferrous sulphate and lactoferrin groups regarding basal hemoglobin.

In the present study we found that Hemoglobin elevation at month-1 and at month-2 after treatment was significantly higher in lactoferrin group than in ferrous sulphate group.

Serum ferritin at month-1 and at month-2 after treatment was significantly higher in lactoferrin group than in ferrous sulphate group.

Our data were in a good agreement with those previously reported by Paesano et al. (2010) who showed that treatment with bovine lactoferrin is slightly more efficient in reestablishing iron storage.

Our results agree with the results of Rezk et al. (2015) that reported increased hemoglobin and total serum iron values to a greater extent in women treated with bLf (bovine lactoferrin) than those observed in women treated orally for 30 days with ferrous sulfate, independently of the trimester of pregnancy and concluded that oral administration of partially ironsaturated bLf enhances intestinal iron delivery better than ferrous sulphate with the absence of side effects resulted in very high compliance among treated women.

We found also that no significant difference between ferrous sulphate and lactoferrin groups regarding basal serum ferritin.

Also our results disagree with Nappi et al. (2009) who showed that bovine lactoferrin probably have the same effect as ferrous sulfate on hematological parameters $(\mathrm{Hb}$, serum iron, serum ferritin rise and TIBC decreases) with significantly fewer gastrointestinal side-effects. This due to his study was done for 30 days only.

We also investigated gastrointestinal side effects of both treatments and observed a higher tolerability of bovine lactoferrin in comparison with ferrous sulfate.

The occurrence of abdominal pain, nausea, vomiting and constipation, in fact, was significantly higher in patients receiving ferrous sulfate in comparison with those receiving lactoferrin. This agreed with Rezk et al. (2015) that reported that gastrointestinal adverse events occurred more frequently with ferrous sulphate than lactoferrin group. Also it agreed with Nappi et al. (2009) who observed a higher tolerability of bovine lactoferrin in comparison with ferrous sulfate.

In the present study, we found that cost effectiveness at month-2 after treatment was significantly more expensive in lactoferrin group than in ferrous sulphate group. This based on the cost of total course of lactoferrin 280 Egyptian pounds, while that of ferrous sulphate is 12 Egyptian pounds. 


\section{LACTOFERRIN VERSUS FERROUS SULPHATE FOR THE TREATMENT...}

This lower incidence of gastrointestinal side effects is due to the different metabolism of the compounds and to the need of administering higher doses of ferrous sulfate. Indeed, fractional iron absorption after oral intake amounts to 10$20 \%$ or less. Thus, $80-90 \%$ of ingested iron remains in the gut lumen and may cause considerable discomfort. These gastrointestinal effects seem to be due to mucosal irritation and to altered gastrointestinal motility and depend on the labile iron concentration in the lumen.

In the upper part of the small intestine, those effects are directly related to the ingested iron dose. Colonic effects correlate less well with the ingested dose, as differences in absorption, intestinal transit time, and binding to dietary ligands interfere with the availability of iron ions.

On the other hand, lactoferrin is thought to be internalized through endocytosis. Iron is then released from Lactoferrin-Fe complex in intestinal cells and lactoferrin is degraded.

The released iron is then transported through the basolateral membrane into the circulation by transferrin. This proposed apical-to-basolateral Lactoferrin-Fe transport mechanism via a specific receptor in the intestinal cells provides an efficient mechanism for iron uptake.

In anemic pregnant women, daily treatment with bovine lactoferrin has a more effect than ferrous sulfate in restoring iron deposits and in contrasting iron deficiency anemia but it causes less gastrointestinal side effects. Considering that one of the major problems of oral supplementation with ferrous sulfate is the lack of compliance because of the high incidence of gastrointestinal side effects, bovine lactoferrin seems to be an appealing alternative strategy in pregnant women with iron deficiency anemia.

Inabilities to design a double blind clinical trial and to record the obstetric outcome of women with IDA were a major limitation of our study.

Future research should address obstetric outcome in terms of gestational age at delivery, mode of delivery, maternal complications (postpartum hemorrhage and defective lactation) and neonatal outcome (neonatal weight, admission to neonatal intensive care unit and neonatal death.

According to the results obtained in this clinical trial, oral lactoferrin was better tolerated and more acceptable with higher increase in mean hemoglobin when compared to oral iron therapy over two month treatment. Oral lactoferrin can be used as a good substitute to oral iron therapy in mild to moderate IDA during pregnancy.

\section{CONCLUSION}

- Oral lactoferrin was better tolerated and more acceptable with higher increase in mean hemoglobin when compared to oral iron therapy over two month treatment.

- Oral lactoferrin can be used as a good substitute to oral iron therapy in mild to moderate IDA during pregnancy.

\section{REFERENCES}

1. Baker HM and Baker EN (2012): A structural perspective on lac- toferrin function. Biochem Cell Biol., 90: 320-328.

2. Duck KA and Connor JR (2016): Iron uptake and transport across physiological barriers. Biometals; 29(4):573-91. 
3. Hutter D, Jaeggi E (2010): Causes and mechanisms of intrauterine hypoxia and its impact on the fetal cardiovascular system: a review. International Journal of Pediatrics; Vol. 2010. published online 2010 Oct 19.

4. Kochhar PK, Kaundal $A$ and Ghosh $P$ (2013): Oral iron in treatment of iron deficiency anemia in pregnancy: A randomized clinical trial. J Obstet Gynaeco. Res., 39: 504-510.

5. Nappi C, Tommaselli GA, Morra I (2009): Efficacy and tolerability of oral bovine lactoferrin compared to ferrous sulfate in pregnant women with iron deficiency anemia: a prospective controlled randomized study. Acta Obstetricia et Gynecologica Scandinavica, 88(9): 1031-1035.

6. Nocerino $\mathbf{N}$, Fulgione $A$, Iannaccone $M$, Tomasetta L, Ianniello F, Martora F, Lelli M, Roveri N, Capuano F and Capparelli R (2014): Biological activity of lactoferrinfuntionalized biomimetic hydroxyapatite nanocrystals. International Journal of Nanomedicine; 9: 1175.
7. Paesano R, Berlutti F, Pietropaoli M, Pantanella F, Pacifici E, Goolsbee $W$ and Valenti P (2010): Lactoferrin efficacy versus ferrous sulfate in curing iron deficiency and iron deficiency anemia inpregnant women. Biometals, 23: 411-417.

8. Rezk M, Kandil M, Dawood R, Shaheen AE, Allam A (2015): Oral lactoferrin versus ferrous sulphate and ferrous fumerate for the treatment of iron deficiency anemia during pregnancy. Journal of Advanced Nutrition and Human Metabolism. 1:1-5.

9. Sharma JB and Meenakshi S (2014): Anemia in Pregnancy. JIMSA., 23(4): 253260.

10. Stedman's Medical Dictionary (28th ed) (2006): Philadelphia: Lippincott Williams \& Wilkins. p. Anemia. ISBN 9780781733908.

11. Tolkien Z, Stecher L, Mander AP, Pereira DI and Powell JJ (2015): Ferrous sulphate supplementation causes significant gastrointestinal side-effects in adults: a systematic review and meta-analysis. PIoS One; 10(2): e0117383. 


\title{
دراسة عشوائيه لمقارنة تأثير الاكتثوفيريز مقابل كبريتات الحلديلدوز

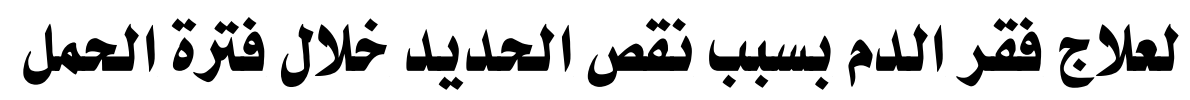

\author{
مفيد فوزي محمد، وائل سليمان طه، محمد فراج إسماعيل فرج
}

قسم امراض النساء والتوليد، كلية الطب، جامعة الأزهر، القاهرة، مصر

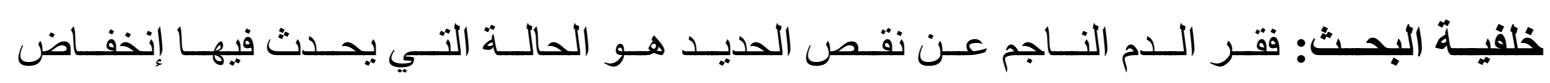

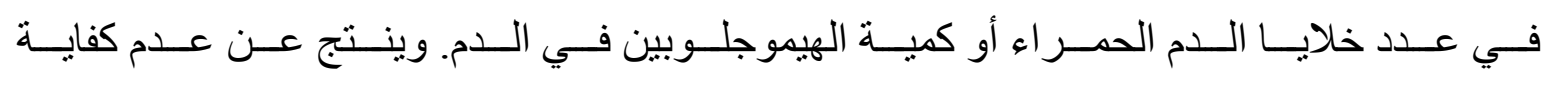

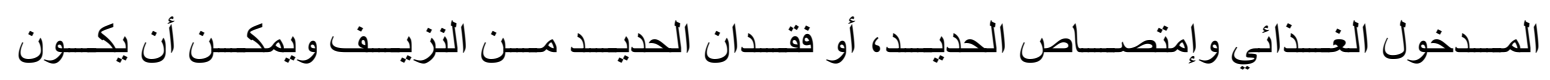



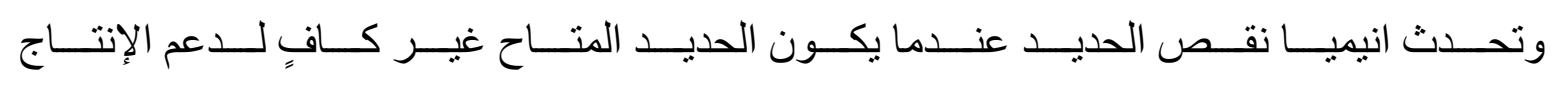
الطبيعي للخلايا الحمر اء وهو أكثر أنواع فقر الدم شيوعًا.

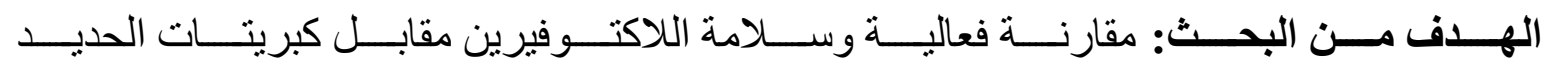
لعلاج فقر الدم الناجم عن نقص الحديد أثناء الحمل.

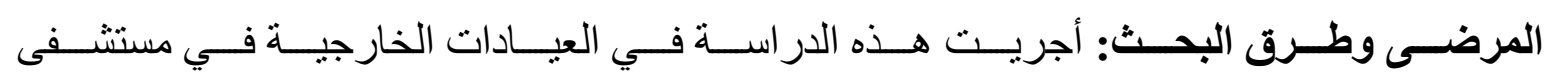

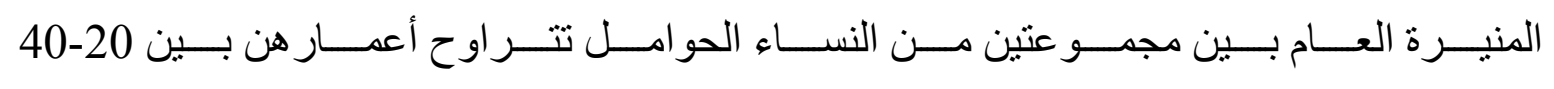

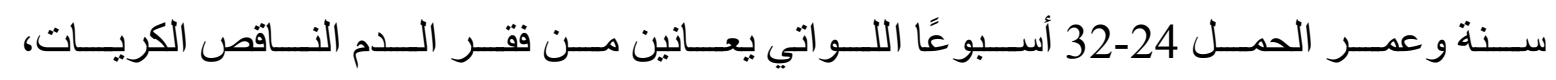

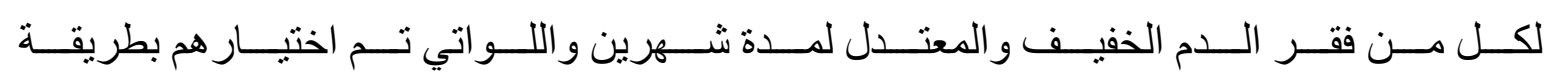
عشو ائية من قبل الكمبيونر.

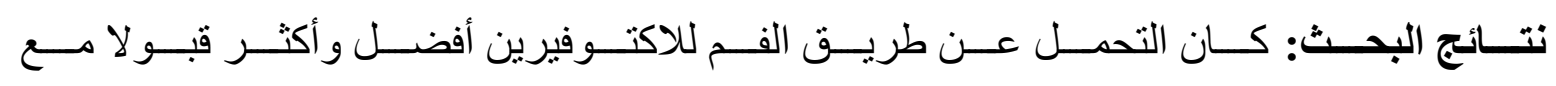

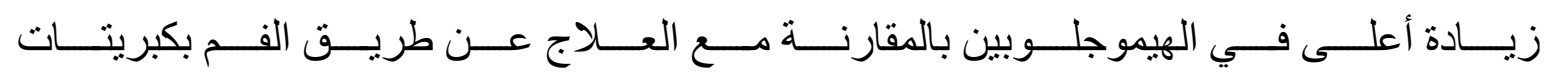
الحديدوز لمدة شهرين.

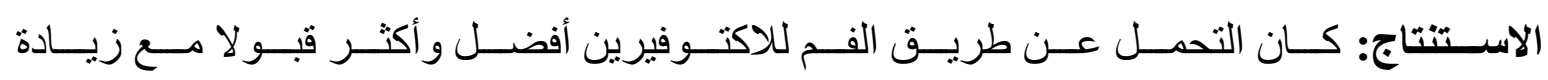

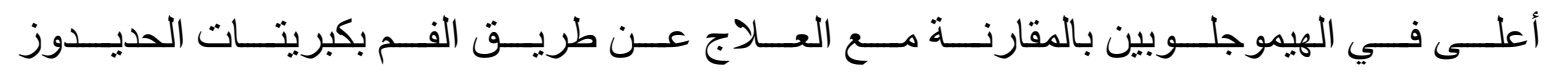
لمدة شهرين. 